\title{
PENGARUH STRATEGI PEMBELAJARAN DAN KEMANDIRIAN TERHADAP HASIL BELAJAR TEKNOLOGI INFORMASI DAN KOMUNIKASI (TIK)
}

\author{
Benard Simanjuntak \\ Guru SMP Swasta Dwi Tunggal Tanjung Morawa, Sumatera Utara \\ Benard_simanjuntak@gmail.com
}

\begin{abstract}
Abstrak: Penelitian ini bertujuan untuk mengetahui: (1) Hasil belajar TIK siswa yang diajarkan dengan strategi pembelajaran tutor sebaya lebih tinggi dari pada siswa yang diajarkan dengan strategi pembelajaran dengan modul. (2) Siswa yang mempunyai kemandirian tinggi memperoleh hasil belajar TIK yang lebih tinggi dari pada siswa yang mempunyai kemandirian rendah. (3) Terdapat interaksi antara strategi pembelajaran dan kemandirian dalam mempengaruhi hasil belajar TIK. Populasinya adalah seluruh siswa kelas VIII sebanyak terdiri dari 3 kelas yakni Kelas VIIII, VIII2, dan VIII3, dimana setiap kelas 40 orang siswa maka jumlah populasi adalah 120 orang. Metode penelitian menggunakan metode quasi eksperimen dengan desain penelitian faktorial $2 \times 2$. Teknik analisis data menggunakan ANAVA pada taraf signifikan $\alpha=0,05$. Hasil analisis penelitian menunjukkan bahwa: (1) hasil belajar TIK siswa yang diajar dengan StrategiPembelajaran Tutor Sebaya lebih tinggi daripada hasil belajar TIK siswa yang diajar dengan Strategi Pembelajaran Modul, (2) terdapat perbedaan yang signifikan antara hasil belajar TIK siswa yang mempunyai Kemandirian tinggi dengan siswa yang mempunyai Kemandirian rendah, dan (3) terdapat interaksi antara Strategi Pembelajaran dan Kemandirian terhadap hasil belajar TIK siswa. Hasil penelitian dapat disimpulkan bahwa StrategiPembelajaran Tutor Sebaya lebih baik diajarkan kepada siswa yang mempunyai Kemandirian tinggi dan Strategi Pembelajaran Modul baik digunakan kepada siswa yang mempunyai Kemandirian rendah dan terdapat interaksi antara Strategi Pembelajaran dan Kemandirian.
\end{abstract}

Kata Kunci: strategi pembelajaran, kemandirian, teknologi informasi dan komunikasi

Abstract: This study aims to find out: (1) The result of ICT learning of students taught by peer tutor learning strategy is higher than the students taught by the learning strategy with the module. (2) Highly self-reliant students gain higher ICT learning outcomes than students with low selfreliance. (3) There is an interaction between learning strategies and independence in influencing ICT learning outcomes. The population is all students of class VIII consisting of 3 classes namely Class VIIII, VIIII, and VIII3, where each class of 40 students then the population is 120 people. The research method used quasi experimental method with $2 \times 2$ factorial research design. Data analysis technique using ANOVA at significant level $\alpha=0,05$. The results of the research analysis showed that: (1) the results of ICT learning of students who were taught with Peer Tutor Strategy were higher than the results of ICT learning of students who were taught by Learning Strategy Module, (2) there was a significant difference between the learning outcomes of ICT students who have high independence with students who have low independence, and (3) there is an interaction between Learning Strategy and Independence on student learning outcomes. The result of this research can be concluded that Peer Tutor Teaching Strategy is better taught to students who have High Independence and Learning Strategy The module is good for students who have low independence and there is interaction between Learning Strategy and Independence.

Keywords: learning strategy, independence, information and communication technology

\section{PENDAHULUAN}

Pendidikan merupakan salah satu upaya untuk meningkatkan kecerdasan dan keterampilan manusia, sehingga kualitas sumberdaya manusia sangat tergantung dari kualitas pendidikan yang dicapai. Pentingnya pendidikan tercermin dalam Undang-Undang Dasar 1945 dan GBHN yang menyatakan bahwa pendidikan merupakan hak setiap warga negara yang bertujuan untuk mencerdaskan kehidupan bangsa, demikian juga di dalam Undang-Undang Republik Indonesia Nomor 20 
Tahun 2003 tentang Sistem Pendidikan Nasional yang tertulis bahwa tujuan pendidikan nasional adalah mencerdaskan kehidupan bangsa, untuk mengembangkan potensi peserta didik agar bisa menjadi manusia yang beriman, bertaqwa kepada Tuhan Yang Maha Esa, berahlak mulia, sehat, berilmu, cakap, kreatif, mandiri, dan menjadi warga negara yang demokratis serta bertanggung jawab. Dengan demikian program pendidikan memiliki andil besar terhadap kemajuan sosial ekonomi untuk kesejahteraan suatu bangsa.

Perkembangan IPTEKS merupakan salah satu tantangan terhadap guru untuk mengikuti perkembangan pada saat ini dan masa yang akan datang, sehingga diharapkan proses pembelajaran dapat dilaksanakan secara efektif dan efisien untuk mencapai tujuan yang diprogramkan serta menyesuaikannya dengan perkembangan di dalam kehidupan masyarakat. Guru di tuntut untuk tetap meningkatkan kualitasnya agar memiliki pengetahuan, kreativitas, sikap dan ketrampilan serta penguasaan teknologi untuk merancang dan menyajikan materi pelajaran yang menarik kepada siswa demi tercapainya hasil belajar yang optimal.

Oleh karena itu upaya meningkatkan kualitas manusia melalui pendidikan terus dilakukan oleh lembaga pemerintah dan masyarakat (stakeholder) yang peduli pendidikan dalam arti luas, seperti penelitian dan pengembangan, pelatihan dan pendidikan/kualifikasi guru serta pengadaan sarana dan prasarana pendidikan baik formal maupun pendidikan non formal. Dalam penyelenggaraan pendidikan di sekolah, program-program sekolah diarahkan pada tujuan jangka panjang pembelajaran yaitu untuk meningkatkan kemampuan siswa, agar ketika mereka sudah meninggalkan bangku sekolah, mereka akan mampu mengembangkan diri sendiri dan mampu memecahkan masalah yang muncul. Dalam upaya mewujudkan tujuan pendidikan aspek proses belajar mengajar merupakan komponen yang mutlak untuk ditelusuri, karena salah satu upaya meningkatkan kualitas mutu lulusan lembaga pendidikan adalah melalui meningkatkan kualitas pembelajaran.

Menurut Rohani (2010: 1) tugas dan tanggung jawab utama seorang guru atau pengajar adalah mengelola pengajaran dengan lebih efektif, dinamis, efisien, dan positif, yang ditandai dengan adanya kesadaran dan keterlibatan aktif di atara dua subjek pengajaran; guru sebagai penginisiatif awal dan pengarah serta pembimbing, sedang peserta didik sebagai yang mengalami dan terlibat aktif untuk memperoleh perubahan diri dalam pengajaran. Hal ini sesuai dengan pendapat Sanjaya (2011: 21-31), fungsi yang dapat diperankan guru dalam pembelajaran yakni sebagai sumber belajar, fasilitator, pengelola, demonstrator, pembimbing, motivator, dan evaluator.

Belajar adalah perubahan perilaku atau potensi perilaku yang relatif permanen yang berasal dari pengalaman dan tidak bisa dinisbahkan ke temporary body states (keadaan tubuh temporer) seperti keadaan yang disebabkan oleh sakit, keletihan atau obatobatan (Hergenhahn, 2008: 8). Kalangan dunia pendidikan menyadari bahwa proses pembelajaran akan lebih efektif apabila siswa berpartisipasi aktif dalam proses pembelajaran. Dengan berpartisipasi aktif dalam pembelajaran, siswa akan mengalami, mengahayati, dan menarik dirinya untuk mempelajari suatu pelajaran.

Mata pelajaran Teknologi Informasi dan Komunikasi (TIK) sebagai salah satu mata pelajaran yang ada pada jenjang pendidikan Sekolah Menengah Pertama (SMP) yang memberikan pengetahuan dan ketrampilan peserta didik dalam memanfaatkan media komputer, sehingga siswa dapat secara maksimal memanfaatkan media tersebut sebagai alat bantu dalam menyelesaikan berbagai pekerjaanya sehari-hari. Oleh karena hal tersebut pengetahuan dan ketrampilan siswa pada mata pelajaran TIK diharapkan mampu menciptakan kemandirian dalam belajar dan mengembangkan pengetahuannya melalui teknologi komunikasi yang ada dalam aplikasi komputer.

Menurut Miarso (2004: 664-665), ciriciri perkembangan IPTEKS dalam era TIK saat ini antara lain; (1) daya muat untuk mengumpulkan, menyiapkan, memanipulasikan, dan menyajikan informasi semakin meningkat, (2) kecepatan penyajian informasi meningkat, (3) miniaturisasi perangkat keras, (4) keragaman pilihan informasi, (5) menurunnya biaya perolehan informasi, (6) mudahnya penggunaan produk teknologi informasi, (7) distribusi informasi yang semakin cepat dan luas, (8) pemecahan masalah yang lebih baik dan dibuatnya prediksi masa depan yang lebih tepat. Oleh karena itu, 
kebijakan pendidikan di Indonesia perlu diarahkan agar mampu menyiapkan sumber daya manusia yang mampu menghadapi tantangan masa depan secara efektif dan efisien, dengan memanfaatkan sumber daya yang ada termasuk TIK.

Dari uraian di atas dapat disimpulkan bahwa pelajaran TIK merupakan mata pelajaran yang sangat penting untuk dikuasai siswa pada zaman IPTEKS sekarang ini, oleh sebab itu pemerintah atau lembaga pengelola pendidikan sudah seharusnya memperhatikan penguasaan mata pelajaran TIK siswanya. Namun pada kenyataannya perolehan hasil belajar TIK khususnya di SMP Swasta Dwi Tunggal Tanjung Morawa masih rendah. Berdasarkan hasil pengamatan peneliti di dalam kelas dan di laboratorium komputer pada saat pembelajaran, siswa cenderung tergantung pada pemecahan masalah yang diberikan oleh guru TIK daripada memecahkan sendiri masalah ataupun bantuan dari teman sekelas. Siswa tidak memiliki sikap untuk mencari pemecahan masalah belajarnya secara mandiri ataupun belajar dari teman sekelasnya. Selain itu, guru dalam mengajar cenderung menggunakan satu metode saja dan lebih mendominasi proses belajar mengajar, dan guru juga kurang memvariasikan model atau strategi pembelajaran dalam proses belajar mengajar. Hasil belajar yang rendah dapat dilihat dari nilai yang diperoleh siswa saat Ujian Akhir Sekolah (UAS) bahwa nilai mata pelajaran TIK masih relatif rendah dibandingkan dengan mata pelajaran lainnya. Dimana nilai rata-rata siswa masih berada di bawah Kriteria Ketuntasan Minimum (KKM) yang ditetapkan pihak sekolah adalah 70 .

Banyak faktor-faktor yang mempengaruhi rendahnya hasil belajar siswa, menurut Muhibbinsyah (2003: 144) faktorfaktor yang mempengaruhi hasil belajar antara lain; (1) faktor internal, yaitu faktor yang berasal dari dalam diri siswa itu sendiri yang meliputi dua aspek yaitu aspek fisiologi yang bersifat jasmaniah dan aspek psikologis yang bersifat rohaniah pada diri siswa, (2) faktor eksternal, yaitu faktor yang berasal dari luar diri siswa dan terdiri dari lingkungan keluarga, sekolah dan masyarakat, (3) faktor pendekatan belajar, yaitu jenis upaya belajar siswa yang meliputi strategi dan metode yang digunakan guru unntuk menyampaikan materi pelajaran. Sedangkan menurut Hamalik (2011: 53) unsurunsur dinamis dalam proses belajar terdiri dari ; (1) motivasi, yakni dorongan untuk berbuat, (2) bahan belajar, yakni materi yang dipelajari, (3) alat bantu belajar, yakni alat yang digunakan untuk membantu siswa melakukan kegiatan belajar, (4) suasana belajar, yakni keadaan lingkungan fisik dan psikologis yang menunjang belajar, dan (5) kondisi subjek belajar, yakni keadaan jasmani dan mental untuk melakukan kegiatan belajar.

Strategi tutor sebaya merupakan upaya untuk mengatasi kecenderungan peran guru yang sangat dominan dalam proses belajar mengajar sehingga mengurangi peran guru dan meningkatkan kemandirian siswa dalam memperoleh pengetahuan dan keterampilan mata pelajaran TIK. Strategi tutor sebaya merupakan suatu strategi pembelajaran untuk memperbaiki pengetahuan dan pemahaman siswa melalui komunikasi antara teman sebaya. Teori yang mendasari strategi tutor sebaya adalah teori pembelajaran sosial oleh Lev Semyonovich Vygotsky. Dalam struktur tutor sebaya ditempatkan seorang siswa sebagai tutor, yaitu mereka yang memiliki pengetahuan yang lebih baik dibanding dengan siswa lainnya sebagai sumber informasi, pengetahuan, dan pemahaman. Strategi pembelajaran tutor sebaya juga menjadikan rasa kebersamaan siswa semakin meningkat yang akhirnya terciptanya kerjasama dalam upaya untuk memperoleh pengetahuan, sikap dan keterampilan.

Selain pemilihan strategi pembelajaran yang tepat, perolehan hasil belajar dipengaruhi oleh kemampuan guru dalam mengenal dan memahami karakteristik siswa. Reigeluth (1983: 20) mengungkapkan bahwa hasil pembelajaran berhubungan dengan interaksi antara strategi pembelajaran dan kondisi pembelajaran yang didalamnya termasuk karakteristik siswa. Selanjutnya Dick and Carey (2005: 43) juga mengungkapkan hal yang sama dengan menyatakan bahwa guru hendaknya mampu untuk mengenal dan mengetahui karakteristik siswa, sebab pemahaman yang baik terhadap proses belajar siswa apabila guru telah mengetahui karakteristik siswanya maka selanjutnya guru dapat menyesuaikannya dengan strategi pembelajaran yang akan digunakan.

Salah satu karateristik siswa adalah kemandirian. Dalam suatu proses belajar mengajar, seorang guru hendaknya mampu mengetahui dan memahami kemandirian yang dimiliki oleh seorang siswa, sebab dengan mengetahui dan memahami kemandirian yang 
dimiliki oleh siswa, seorang guru dapat menyusun dan membuat materi ajar yang relevan untuk membantu dan mengarahkan kesiapan siswa untuk menerima materi pelajaran.

Berdasarkan uraian latar belakang yang telah dikemukakan di atas, maka dapat diidentifikasi masalah-masalah yang berkaitan dengan penelitian ini yaitu: Faktor-faktor apa saja yang mempengaruhi hasil belajar TIK di Siswa Kelas VIII SMP Swasta Dwi Tunggal Tanjung Morawa? Apakah penyebab rendahnya hasil belajar TIK yang di dapat oleh siswa? Apakah rendahnya hasil belajar disebabkan oleh lingkungan belajar yang tidak dinamis? Bagaimana guru dalam melaksanakan pembelajaran dan menerapkan teori-teori belajar kepada siswa? Apakah kelengkapan sarana dan prasarana belajar mempengaruhi hasil belajar siswa? Bagaimana sebaiknya strategi pembelajaran yang digunakan untuk meningkatkan hasil belajar siswa? Apakah guru telah merencanakan proses pembelajaran dengan baik? Bagaimana guru mempertimbangkan karakteristik siswa dan hakikat mata pelajaran yang diasuhnya dalam pemilihan strategi pembelajaran ? Apakah guru menggunakan berbagai strategi pembelajaran sesuai dengan tujuan dan bahan ajar yang disampaikan? Strategi pembelajaran apa yang selama ini digunakan oleh guru untuk meningkatkan kemandirian belajar siswa? Apakah guru telah memperhatikan karakteristik siswa pada waktu pelaksanaan pembelajaran? Apakah guru telah menggunakan alat atau media pembelajaran yang tepat untuk membantu siswa dalam meningkatkan hasil belajar TIK? Apakah guru telah memanfaatkan bahan-bahan bacaan atau bahan pustaka yang tersedia untuk meningkatkan kemandirian belajar siswa? Apakah terdapat pengaruh kemandirian siswa terhadap hasil belajar TIK? Apakah terdapat pengaruh antara strategi pembelajaran terhadap hasil belajar TIK? Apakah terdapat interaksi antara strategi pembelajaran dan kemandirian siswa terhadap hasil belajar TIK?

Berdasarkan indentifikasi masalah yang telah dikemukakan di atas, banyak pertanyaan yang akan di jawab dalam penelitian ini. Mengingat keterbatasan dan kemampuan peneliti baik dari ruang lingkup lokasi penelitian, subjek penelitian, waktu penelitian, dan biaya penelitian maka perlu dibatasi ruang lingkup pembahasan masalah penelitian agar lebih efektif dan efisien. Penelitian ini dibatasi pada masalah Siswa Kelas VIII SMP Swasta Dwi Tunggal Tanjung Morawa, sebagai berikut: perbedaan hasil belajar TIK menggunakan strategi pembelajaran tutor sebaya dengan strategi pembelajaran dengan modul, kemandirian belajar siswa dikelompokkan menjadi dua yaitu kemandirian belajar tinggi dan kemandirian belajar rendah, hasil belajar siswa dibatasi pada ranah kognitif taksonomi Bloom dengan menggunakan tes hasil belajar yang telah divalidkan. Berdasarkan uraian latar belakang masalah, identifikasi masalah, dan pembatasan masalah, yang menjadi rumusan masalah dalam penelitian ini adalah sebagai berikut: apakah hasil belajar TIK siswa yang diajarkan dengan strategi pembelajaran tutor sebaya lebih tinggi dari pada siswa yang diajarkan dengan strategi pembelajaran dengan modul?, apakah siswa yang mempunyai kemandirian tinggi memperoleh hasil belajar TIK yang lebih tinggi dari pada siswa yang mempunyai kemandirian rendah?, Apakah terdapat interaksi antara strategi pembelajaran dan kemandirian dalam mempengaruhi hasil belajar TIK?

Penelitian ini bertujuan untuk mengetahui: hasil belajar TIK siswa yang diajarkan dengan strategi pembelajaran tutor sebaya lebih tinggi dari pada siswa yang diajarkan dengan strategi pembelajaran dengan modul, siswa yang mempunyai kemandirian tinggi memperoleh hasil belajar TIK yang lebih tinggi dari pada siswa yang mempunyai kemandirian rendah, terdapat interaksi antara strategi pembelajaran dan kemandirian dalam mempengaruhi hasil belajar TIK.

Berdasarkan teori-teori dan kerangka berpikir yang dikemukakan di atas, selanjutnya dikemukakan hipotesis penelitian sebagai berikut: (1) Hasil belajar siswa yang diajar dengan strategi pembelajaran tutor sebaya memperoleh hasil belajar yang lebih tinggi dibandingkan dengan siswa yang diajarkan dengan strategi pembelajaran dengan modul pada mata pelajaran TIK; (2) Hasil belajar siswa yang memiliki kemandirian tinggi akan memperoleh hasil belajar yang lebih tinggi dibandingkan dengan siswa yang memiliki kemandirian rendah pada mata pelajaran TIK; dan (3) Terdapat interaksi strategi pembelajaran dan kemandirian terhadap hasil belajar TIK. 


\section{METODE}

Penelitian dilakukan di SMP Swasta Dwi Tunggal Kecamatan Tanjung Morawa Kab. Deli Serdang. Waktu penelitian ini disesuaikan dengan kalender pendidikan untuk pelaksanaan perlakuan dalam bentuk kegiatan belajar mengajar atau proses pembelajaran.

Populasi dalam penelitian ini adalah seluruh siswa kelas VIII SMP Swasta Dwi Tunggal Tanjung Morawa yang menerima mata pelajaran TIK. Siswa kelas VIII SMP Swasta Dwi Tunggal terdiri dari 3 kelas yakni Kelas VIII1, VIII2, dan VIII3, setiap kelas 40 orang siswa maka jumlah populasi adalah 120 orang. Pembagian kelas tidak dilakukan berdasarkan ranking, sehingga tidak terdapat kelas unggulan dan karakteristik siswanya heterogen.

Penarikan sampel dilakukan dengan teknik cluster random sampling, selanjutnya dengan menggunakan teknik tersebut ditentukan 2 (dua) kelas yang menjadi sampel penelitian, yaitu kelas VIII1 dan VIII3. Kemudian untuk menentukan jenis strategi pembelajaran ditentukan dengan tehnik yang sama yaitu kelas VIII3 menggunakan strategi pembelajaran tutor sebaya dan kelas VIII1 menggunakan strategi pembelajaran modul.
Pengambilan sampel penelitian ini dilakukan berdasarkan tingkat kemandirian yang dimiliki siswa pada setiap kelas. Dari tiap kelas sampel masing-masing diambil berdasarkan siswa yang memiliki kemandirian tinggi dan siswa yang memiliki kemandirian rendah. Kemandirian siswa diurutkan dari tingkat yang rendah ke tingkat tinggi berdasarkan hasil perhitungan jumlah butir angket yang diisi oleh sampel dan diadakan sebelum perlakuan penelitian dimulai. Hasil pengukuran dijadikan pedoman dalam pengelompokan subjek penelitian, oleh karena itu angket kemandirian siswa diberikan pada saat sebelum perlakuan eksperimen.

Metode penelitian yang dilakukan adalah penelitian eksperimen semu (Quase Experiment) dengan rancangan penelitian sebagai dasar pelaksanaan penelitian adalah untuk membedakan pengaruh strategi pembelajaran Tutor Sebaya dan strategi pembelajaran dengan Modul terhadap hasil belajar TIK ditinjau dari kemandirian tinggi dan kemandirian rendah yang kelas perlakuan telah terbentuk sebelumnya, sehingga rancangan penelitian adalah dengan rancangan faktorial 2 $\mathrm{x} 2$.

Tabel. 1. Rancangan Penelitian

\begin{tabular}{|c|l|l|}
\hline \multirow{2}{*}{ Kemandirian (B) } & \multicolumn{2}{|c|}{ Strategi Pembelajaran (A) } \\
\cline { 2 - 3 } & \multicolumn{1}{|c|}{ Tutor Sebaya (A1) } & \multicolumn{1}{c|}{ Modul (A2) } \\
\hline Tinggi (B1) & B1A1 & B1A2 \\
\hline Rendah (B2) & B2A1 & B2A2 \\
\hline
\end{tabular}

Dari hasil data tes hasil belajar siswa yang diperoleh dari tes hasil belajar TIK kemudian dihitung total skor dan rata-rata skor tiap sel menurut tabel Anava yang selanjutnya berfungsi sebagai penolong untuk ANAVA seperti ditunjukkan pada Tabel 2 berikut ini:

Tabel 2. Ringkasan Data Untuk Setiap Kelompok Perlakuan

\begin{tabular}{|c|c|c|c|c|}
\hline Kemandirian & Statistik & $\begin{array}{c}\text { Pembelajaran } \\
\text { Tutor Sebaya }\end{array}$ & $\begin{array}{c}\text { Pembelajaran } \\
\text { Modul }\end{array}$ & Jumlah \\
\hline \multirow{4}{*}{ Tinggi } & $\mathrm{N}$ & 23 & 21 & 44 \\
\cline { 2 - 5 } & $\Sigma \mathrm{X}$ & 762 & 630 & 1392 \\
\cline { 2 - 5 } & $\Sigma \mathrm{X}^{2}$ & 25414 & 19144 & 44558 \\
\cline { 2 - 5 } & $\overline{\mathrm{X}}$ & 33.13 & 30 & 31.64 \\
\hline \multirow{4}{*}{ Rendah } & $\mathrm{S}^{2}$ & 7.66 & 12.2 & 12.1 \\
\cline { 2 - 5 } & $\mathrm{N}$ & 17 & 19 & 36 \\
\cline { 2 - 5 } & $\mathrm{NX}$ & 460 & 544 & 1004 \\
\cline { 2 - 5 } & $\bar{*}$ & 12650 & 15840 & 28490 \\
\cline { 2 - 5 } & $\overline{\mathrm{X}}$ & 27.06 & 28.63 & 28,63 \\
\hline \multirow{3}{*}{ Jumlah } & $\mathrm{S}^{2}$ & 12.68 & 14.69 & 13.99 \\
\cline { 2 - 5 } & $\mathrm{N}$ & 40 & 40 & 80 \\
\hline
\end{tabular}




\begin{tabular}{|c|c|c|c|c|} 
& $\Sigma \mathrm{X}^{2}$ & 38064 & 34984 & 73048 \\
\cline { 2 - 5 } & $\overline{\mathrm{X}}$ & 30.55 & 29.35 & \\
\cline { 2 - 5 } & $\mathrm{S}^{2}$ & 18.77 & 13.52 & \\
\hline
\end{tabular}

Berdasarkan perhitungan dari Tabel 2 di atas, maka dihitung Anava faktorial $2 \times 2$ dan diperoleh ringkasan hasil Anava faktorial $2 \times 2$ yang digunakan untuk menguji hipotesis penelitian sebagaimana dirumuskan seperti ditunjukkan pada Tabel 3 berikut ini:

Tabel 3. Ringkasan Hasil Perhitungan ANAVA Faktorial 2 x 2

\begin{tabular}{|l|r|r|r|r|r|}
\hline \multicolumn{1}{|c|}{ Sumber Varians } & \multicolumn{1}{c|}{ JK } & \multicolumn{1}{c|}{ dk } & \multicolumn{1}{c|}{ RJK } & \multicolumn{1}{c|}{ Fo } & \multicolumn{1}{c|}{ Ft } \\
\hline $\begin{array}{l}\text { Antar Pembelajaran Tutor Sebaya } \\
\text { dengan Modul }\end{array}$ & 120,51 & 1 & 120,51 & 4,441 & 3,98 \\
\hline $\begin{array}{l}\text { Antar Kemandirian Tinggi } \\
\text { dengan Rendah }\end{array}$ & 303,375 & 1 & 303,375 & 11,182 & 3,98 \\
\hline Kolom dan Baris (Interaksi) & 383,074 & 1 & 383,074 & 14,119 & 3,98 \\
\hline Dalam Kelompok (Kekeliruan) & 2089,027 & 77 & 27,13 & & \\
\hline Total & 2895,986 & 80 & & & \\
\hline
\end{tabular}

Berdasarkan Tabel 3 di atas maka untuk pengaruh pembelajaran Tutor Sebaya dengan Pembelajaran Modul diperoleh berdasarkan $\mathrm{F}_{\text {hitung }}=4,441$ sedangkan pengujian untuk $\alpha=5$ $\%$ dengan $\mathrm{dk}=(1,80)=3,98$, sehingga dapat dinyatakan bahwa $F_{h}=4,441>3,98$. Sehingga dapat dikatakan bahwa hasil pengujian menolak $\mathrm{H}_{\mathrm{O}}$ dan menerima $\mathrm{Ha}$ dalam taraf signifikan 5\%. Dengan demikian hipotesis penelitian yang menyatakan hasil belajar siswa yang diajar dengan strategi pembelajaran tutor sebaya memperoleh hasil belajar yang lebih tinggi dibandingkan dengan siswa yang diajarkan dengan strategi pembelajaran dengan modul pada mata pelajaran TIK teruji kebenarannya.

Berdasarkan Tabel 3 di atas, maka untuk pengaruh Kemandirian Tinggi dengan Kemandirian Rendah diperoleh bahwa $\mathrm{F}_{\text {hitung }}=$ 11,182 sedangkan pengujian untuk $\alpha=5 \%$ dengan $\mathrm{dk}=(1,80)=3,98$ sehingga dapat dinyatakan bahwa $F_{h}=11,182>3,98$. Sehingga dapat dikatakan bahwa hasil pengujian menolak $\mathrm{H}_{\mathrm{O}}$ dan menerima $\mathrm{Ha}$ dalam taraf signifikan $5 \%$. Dengan demikian hipotesis penelitian yang menyatakan hasil belajar siswa yang memiliki kemandirian tinggi akan memperoleh hasil belajar yang lebih tinggi dibandingkan dengan siswa yang memiliki kemandirian rendah pada mata pelajaran TIK teruji kebenarannya.

Berdasarkan Tabel 3 di atas, maka pengaruh interaksi diperoleh $F_{\text {hitung }}=14,119$ sedangkan pengujian untuk $\alpha=5 \%$ dengan $\mathrm{dk}=$ $(1,80)=3,98$ sehingga dapat dinyatakan bahwa $F_{h}=14,119>3,98$. Sehingga dapat dikatakan bahwa hasil pengujian menolak $\mathrm{H}_{\mathrm{O}}$ dan menerima $\mathrm{Ha}$ dalam taraf signifikan $5 \%$. Dengan demikian hipotesis penelitian yang menyatakan ada interaksi secara signifikan antara strategi pembelajaran dan kemandirian terhadap hasil belajar TIK teruji kebenarannya.

Adanya interaksi antara kedua variabel di atas, perlu dilihat pengaruh skor rata-rata sampel yang telah memberikan peningkatan hasil belajar yang lebih baik, sehingga perlu uji lanjutan dengan menggunakan uji Scheffe'. Pengujian lanjutan dengan uji Scheffe' didasarkan pada sel setiap sampel anava memiliki ukuran sampel yang berbeda. Hasil ringkasan Uji Lanjut dengan Uji Scheffe' seperti pada Tabel 4 berikut ini:

Tabel 4 Ringkasan Hasil Uji Lanjut dengan Uji Scheffe'

\begin{tabular}{|c|c|c|c|c|}
\hline No. & $\begin{array}{c}\text { Kelompok Siswa Yang } \\
\text { Dibandingkan }\end{array}$ & Qhitung & $\begin{array}{c}\mathrm{Q}_{\text {Tabel }} \\
\alpha=5 \%\end{array}$ & Keterangan \\
\hline & $A_{1} B_{1}-A_{2} B_{1}$ & 2,49 & 2,74 & Tidak Signifikan \\
\hline & $A_{1} B_{2^{-}} A_{2} B_{2}$ & 2,17 & 2,74 & Tidak Signifikan \\
\hline & $A_{1} B_{1}-A_{1} B_{2}$ & 14,04 & 2,74 & Signifikan \\
\hline & $A_{2} B_{1}-A_{2} B_{2}$ & 3,31 & 2,74 & Signifikan \\
\hline & $A_{1} B_{1}-A_{2} B_{2}$ & 7,72 & 2,74 & Signifikan \\
\hline & $A_{2} B_{1}-A_{l} B_{2}$ & 7,22 & 2,78 & Signifikan \\
\hline
\end{tabular}


Dengan memperhatikan perbandingan nilai kritis untuk beda rata-rata Strategi Pembelajaran Tutor sebaya dengan kemandirian Tinggi dengan Strategi Pembelajaran Modul kemandirian Tinggi didapat $\mathrm{Q}_{\text {hitung }}=2,49$ dengan nilai $\mathrm{Q}_{\text {tabel }(5 \%)}=2,74$ ternyata $\mathrm{Q}_{\text {hitung }}<\mathrm{Q}$ Tabel sehingga dapat dikatakan tidak ada perbedaan yang sangat signifikan antara kelompok siswa yang mempunyai Kemandirian tinggi yang diajar dengan menggunakan Strategi Pembelajaran Tutor sebaya dan Strategi Pembelajaran Modul. Dalam hal ini perbedaan hasil belajar dapat dilihat dari hasil belajar TIK kelompok siswa yang mempunyai Kemandirian tinggi yang diajar menggunakan Strategi Pembelajaran Tutor sebaya yang mempunyai rata-rata $(\bar{X})=33,13$ dan hasil belajar TIK yang diajar menggunakan Strategi Pembelajaran Modul mempunyai rata-rata $(\bar{X})$ $=30$.

Kemudian nilai kritis untuk beda ratarata siswa yang diajar dengan strategi pembelajaran tutor sebaya dan Modul dengan kemandirian rendah didapat $\mathrm{Q}_{\text {hitung }}=2,17$ dengan nilai $\mathrm{Q}_{\text {Tabel }(5 \%)}=2,74$ ternyata $\mathrm{Q}_{\text {hitung }}<$ $\mathrm{Q}$ tabel sehingga dapat dikatakan ada perbedaan yang signifikan antara kelompok siswa yang diajar menggunakan Strategi Pembelajaran Tutor sebaya dan Modul dengan siswa memiliki Kemandirian Rendah. Dalam hal ini perbedaan hasil belajar dapat dilihat dari hasil belajar TIK kelompok siswa yang diajar menggunakan Strategi Pembelajaran Tutor sebaya untuk Kemandirian Rendah mempunyai rata-rata $(\bar{X}$ $=27,1)$ dan untuk kelompok siswa yang diajar menggunakan Strategi Pembelajaran Modul untuk Kemandirian rendah mempunyai rata-rata sebesar $(\bar{X}=28,63)$.

Kemudian nilai kritis untuk beda ratarata Tutor sebaya dengan kemandirian Tinggi dengan Tutor sebaya kemandirian rendah didapat $\mathrm{Q}_{\text {hitung }}=14,04$ dengan nilai $\mathrm{Q}_{\text {tabel }}(5 \%)=$ 2,74 ternyata $\mathrm{Q}$ hitung $>\mathrm{Q}$ tabel sehingga dapat dikatakan ada perbedaan yang signifikan antara kelompok siswa yang diajar menggunakan strategi pembelajaran Tutor Sebaya dengan Kemandirian tinggi dan Kemandirian rendah. Dalam hal ini perbedaan hasil belajar dapat dilihat dari hasil belajar TIK kelompok siswa yang diajar menggunakan strategi pembelajaran Tutor sebaya untuk Kemandirian tinggi mempunyai rata-rata $(\bar{X})=33,13$ dan untuk
Kemandirian rendah mempunyai rata-rata $\operatorname{sebesar}(\bar{X})=27,1$.

Selanjutnya nilai kritis untuk beda ratarata strategi pembelajaran Modul dengan kemandirian tinggi dengan Modul rendah Qhitung $=3,31$ dengan nilai $\mathrm{Q}_{\text {tabel }}(5 \%)=2,74$ ternyata $\mathrm{Q}$ hitung > $\mathrm{Q}$ tabel sehingga dapat dikatakan ada perbedaan yang signifikan antara kelompok siswa yang diajar menggunakan Strategi Pembelajaran Modul dengan Kemandirian tinggi dan Kemandirian rendah. Dalam hal ini perbedaan hasil belajar dapat dilihat dari hasil belajar TIK kelompok siswa yang diajar menggunakan Strategi Pembelajaran Modul untuk Kemandirian tinggi mempunyai rata-rata $(\bar{X})=30,41$ dan untuk Kemandirian rendah mempunyai rata-rata $(\bar{X})=28,63$.

Selanjutnya nilai kritis untuk beda ratarata strategi pembelajaran Tutor Sebaya Kemandirian tinggi dengan strategi pembelajaran Modul kemandirian rendah didapat $\mathrm{Q}_{\text {hitung }}=7,72$ dengan nilai $\mathrm{Q}_{\text {tabel }}(5 \%)=$ 2,74 ternyata $\mathrm{Q}$ hitung $>\mathrm{Q}$ tabel sehingga dapat dikatakan terdapat perbedaan yang signifikan antara kelompok siswa yang diajar menggunakan Strategi Pembelajaran Tutor sebaya untuk Kemandirian tinggi dan kelompok siswa yang diajar menggunakan Strategi Pembelajaran Modul untuk Kemandirian rendah. Dalam hal ini perbedaan hasil belajar dapat dilihat dari hasil belajar TIK kelompok siswa yang diajar menggunakan Strategi Pembelajaran Tutor sebaya untuk Kemandirian rendah mempunyai rata-rata $(\bar{X})=33,13$ dan hasil belajar TIK kelompok siswa yang diajar menggunakan Strategi Pembelajaran Modul untuk Kemandirian rendah mempunyai rata-rata $(\bar{X})=28,63$.

Selanjutnya nilai kritis untuk beda ratarata strategi pembelajaran Modul kemandirian tinggi dengan strategi pembelajaran Tutor Sebaya kemandirian rendah didapat $\mathrm{Q}_{\text {hitung }}=$ 17,22 dengan nilai $Q$ tabel $(5 \%)=2,74$ ternyata $Q$ hitung > $\mathrm{Q}$ tabel sehingga dapat dikatakan ada perbedaan yang signifikan antara kelompok siswa yang diajar menggunakan Strategi Pembelajaran Modul untuk Kemandirian tinggi dan kelompok siswa yang diajar menggunakan Strategi Pembelajaran Tutor sebaya untuk Kemandirian rendah. Dalam hal ini perbedaan hasil belajar dapat dilihat dari hasil belajar TIK kelompok siswa yang diajar menggunakan Strategi Pembelajaran Modul untuk 
Kemandirian tinggi mempunyai rata-rata $(\bar{X})$ $=30,0$ dan hasil belajar TIK kelompok siswa yang diajar menggunakan Strategi Pembelajaran Tutor sebaya untuk Kemandirian rendah mempunyai rata-rata $(\bar{X}=27,1)$.

\section{PEMBaHASAN}

Hasil pengujian hipotesis pertama menunjukkan bahwa hasil belajar TIK lebih tinggi jika diajarkan dengan strategi pembelajaran Tutor Sebaya dibandingkan dengan siswa yang diajarkan dengan strategi pembelajaran Modul. Hal ini menunjukkan bahwa strategi pembelajaran Tutor Sebaya dinilai lebih unggul dibandingkan dengan strategi Modul walaupun demikian bukan berarti bahwa strategi Tutor Sebaya merupakan satu-satunya strategi yang paling baik untuk semua situasi pembelajaran dan bukan pula berarti strategi Modul tidak baik digunakan dalam pembelajaran.

Pada dasarnya kegiatan pembelajaran yang menggunakan strategi pembelajaran Tutor Sebaya menitik beratkan pada suasana yang akrab dalam belajar kelompok dan mendorong peningkatan kemampuan siswa dalam memecahkan berbagai permasalahan selama pembelajaran, siswa lebih leluasa bertanya pada teman tutornya. Siswa bebas mengajukan pertanyaan-pertanyaan yang bersifat terbuka serta teknik ini mendorong siswa membuat interprestasi, penjelasan dan menyusun hipotesis/pendapat. Cara belajar yang demikian menyebabkan pengetahuan dalam ingatan dapat bertahan lama, mempunyai efek pada proses belajar yang lebih baik dibandingkan dengan strategi pembelajaran Modul. Hal ini didasarkan pada suasana belajar yang berlangsung dalam interaksi yang saling percaya, terbuka dimana siswa percaya kepada pimpinan kelompok (tutor). Hal ini didukung dengan pernyataan Berliner and Calfee (1996:848) yang menyatakan strategi pembelajaran tutor sebaya memberi dampak positif yang luas antara lain: (1) Mengembangkan sikap dan persahabatan yang lebih besar, (2) Sebagai jalan keluar bagi mahasiswa yang mempunyai hambatan secara akademik, (3) Meningkatkan harga diri dan rasa percaya diri dalam prestasi akademik, (4) Perolehan dukungan yang lebih dari teman sekelas, (5) Memanfaatkan waktu yang lebih banyak dalam tugas-tugas akademik, (6) kerja sama.
Berdasarkan temuan yang dikemukakan bahwa secara umum perbedaan antara strategi pembelajaran Tutor Sebaya dengan pembelajaran mengunakan Strategi Pembelajaran Modul. terletak dalam berbagai aspek antara lain, bahwa pembelajaran menggunakan Strategi Pembelajaran Modul menunjukkan ciri pembelajaran yang mengharapkan guru menyediakan materi bahan ajar sebagai sumber informasi, sedangkan pada strategi pembelajaran Tutor Sebaya siswa akan menemukan sendiri lebih banyak informasi melalui kerjasama kelompok. Pembelajaran dengan menggunakan Strategi Pembelajaran Modul dan strategi pembelajaran Tutor Sebaya dipandang dapat meningkatkan hasil belajar TIK karena mampu memberikan kesempatan kepada siswa untuk mengembangkan potensi intelektualnya yang diserap dari teman siswa sebagai tutor. Hal ini juga didukung oleh penelitian yang relevan oleh Azimah \& Rusjiono (2010) tentang pengaruh penggunaan strategi pembelajaran tutor sebaya terhadap hasil belajar TIK, menyimpulkan bahwa pembelajaran tutor sebaya baik diterapkan di sekolah hanya beberapa aspek yang perlu ditingkatkan yaitu penjelasan guru mengenai langkah-langkah kegiatan pembelajaran tutor sebaya.

Seperti diketahui bahwa Kemandirian merupakan upaya untuk menambah pengetahuan, melalui Kemandirian dirasakan sangat berpengaruh terhadap kemampuan siswa dalam mengembangkan materi yang sedang dipelajari. Penguasaan materi siswa melalui mencari informasi di luar penyampaian materi di sekolah akan membantu siswa dalam melakukan aktivitas di sekolah. Dengan demikian bagi siswa yang memiliki kemampuan memahami konsep di luar kegiatan proses belajar mengajar akan lebih baik dan lebih mudah mempelajari suatu konsep karena telah mempelajari konsep atau prinsip lebih dahulu. Dengan adanya pengetahuan dasar seperti ini, siswa akan dapat menyusun kesimpulan dengan lebih mudah tentang apa yang dipelajari. Setelah itu, siswa dapat mengaplikasikan konsep-konsep atau prinsipprinsip itu dalam pemecahan masalah yang dihadapi baik dalam kegiatan belajar di kelas maupun dalam kehidupan masyarakat secara langsung. Kondisi ini teruji secara empiris dengan temuan penelitian yang membuktikan bahwa terdapat perbedaan hasil belajar siswa yang signifikan antara kelompok yang memiliki 
Kemandirian tinggi dengan kelompok yang memiliki Kemandirian rendah.

Kemandirian merupakan salah satu karakteristik yang memiliki siswa. Di dalam proses pembelajaran, guru sebagai motivator haruslah mengetahui dan mengenal karakteristik siswa, maka guru dapat menggunakan strategi pembelajaran, pendekatan yang sesuai dengan karakteristik siswa selain karakteristik materi pembelajaran. Kemandirian memiliki potensi untuk memberikan pengaruh terhadap capaian hasil belajar. Kemandirian merupakan bagian dan motivasi seseorang yang mendorong perilaku untuk mengejar suatu objek, yakni prestasi. Bila kemandirian belajar tinggi, maka kegiatan belajarpun meningkat, dalam arti pembelajaran akan semakin aktif dan sungguh-sungguh untuk mencapai tujuan, sebab tujuan sudah merupakan kebutuhan baginya. Oleh sebab itu, dengan perbedaaan Kemandirian siswa bagaimana upaya yang digunakan guru untuk menumbuh dan meningkatkan Kemandirian siswa, sehingga para siswa lebih giat dan sungguh dalam belajar untuk memperoleh hasil yang lebih baik daripada hasil yang sudah pernah diperoleh sebelumnya.

Kemandirian sangat berpengaruh terhadap peningkatan hasil belajar siswa pada mata pelajaran TIK. Hal ini terbukti dari hasil temuan yang menguatkan bahwa siswa yang memiliki Kemandirian yang tinggi lebih menguasai suasana pembelajaran, lebih aktif dalam kelas, dan lebih dominan dalam situasi tanya jawab. Sedangkan bagi siswa yang kurang mandiri, cenderung lebih pasif, dan kelihatan ragu-ragu dalam memberikan pendapat, selalu membuat keributan dan bahkan cenderung terlambat atau ketinggalan dalam memahami isi materi yang diajarkan. Berdasarkan hasil penelitian yang diperoleh memberikan gambaran bahwa dalam proses pembelajaran TIK sangat perlu untuk memperhatikan tingkat Kemandirian yang dimiliki siswa.

Dari hasil perhitungan menemukan bahwa terdapat interaksi antara strategi pembelajaran dengan kemampuan Kemandirian dalam mempengaruhi hasil belajar siswa pada mata pelajaran TIK. Hal ini memberikan indikasi bahwa perlakuan terhadap kelompok siswa yang memiliki Kemandirian tinggi berbeda dengan kelompok siswa yang memiliki Kemandirian rendah, artinya bahwa salah satu dari kedua kelompok akan menghasilkan hasil belajar yang lebih baik bila diajarkan dengan strategi pembelajaran Tutor Sebaya dan yang lainnya akan lebih baik bila diajar dengan menggunakan Strategi Pembelajaran Modul.

Berdasarkan dari hasil penelitian, menunjukkan bahwa bagi kelompok siswa yang memiliki kemampuan Kemandirian tinggi, akan memperoleh rata-rata hasil belajar lebih baik bagi yang diajar dengan strategi pembelajaran Tutor Sebaya sedangkan kelompok siswa yang memiliki kemampuan Kemandirian rendah ratarata nilai hasil belajar yang diperoleh lebih baik bagi yang diajar dengan menggunakan Strategi Pembelajaran Modul. Hal ini dapat dijelaskan bahwa bagi siswa yang memiliki kemampuan Kemandirian tinggi akan lebih menunjukkan aktivitas yang lebih aktif dalam pembelajaran, lebih senang dengan berdiskusi dan tertarik dengan teman sebaya, sehingga karakteristik ini akan lebih sesuai dengan Strategi Pembelajaran Tutor Sebaya. Sebaliknya bagi siswa yang memiliki Kemandirian rendah mereka selalu ragu-ragu dalam mengungkapkan pendapat bahkan kurang aktif akibat kurangnya pengetahuan tambahan yang dimiliki, sehingga mereka lebih senang untuk mencari informasi melalui penyajian guru sehingga kondisi ini akan membantu untuk meningkatkan hasil belajar mereka. Berdasarkan temuan ini memberikan gambaran bahwa penerapan strategi pembelajaran pada TIK perlu memperhatikan Kemandirian yang dimiliki siswa untuk membantu siswa mencapai hasil belajar yang lebih baik.

Temuan penelitian yang lebih unik menunjukkan bahwa hasil belajar kelompok siswa yang memiliki kemampuan Kemandirian tinggi yang diberi strategi pembelajaran Tutor Sebaya lebih tinggi dibandingkan dengan dengan kelompok perlakuan yang lain, hal ini memberikan indikasi bahwa strategi pembelajaran Tutor Sebaya memang memberikan pengaruh yang lebih dominan dalam meningkatkan hasil belajar siswa, sedangkan tiga kelompok perlakuan lainnya menunjukkan perbedaan nilai hasil belajar siswa yang signifikan. Artinya bahwa interaksi antara strategi pembelajaran dengan kemampuan Kemandirian terjadi pada nilai rata-rata hasil belajar yang rendah, sehingga kelihatan bahwa rata-rata nilai hasil belajar siswa yang tinggi didominasi pada kelompok strategi pembelajaran Tutor Sebaya bagi siswa yang memiliki kemampuan Kemandirian tinggi. 
Hasil penelitian ini juga memberikan gambaran bahwa rata-rata hasil belajar siswa yang diberikan pembelajaran Tutor Sebaya memang menunjukkan kecenderungan untuk memperoleh hasil belajar yang tinggi bagi siswa yang memiliki Kemandirian tinggi, sedangkan bagi siswa yang memperoleh pembelajaran menggunakan Strategi Pembelajaran Modul menunjukkan perubahan peningkatan hasil belajar yang tidak begitu signifikan antara kelompok yang memiliki Kemandirian tinggi dengan yang berkemampuan Kemandirian rendah.

Hasil penelitian ini juga menemukan bahwa tidak terdapat interaksi antara kelompok siswa yang diajar dengan Strategi Pembelajaran Tutor Sebaya dengan Kemandirian rendah dengan kelompok siswa yang diajar dengan Strategi Pembelajaran Modul yang memiliki Kemandirian rendah. Hal ini menunjukkan bahwa strategi pembelajaran yang sebenarnya lebih dominan mempengaruhi hasil belajar siswa, dan bukan hanya karena Kemandirian. Walaupun demikian diharapkan melalui temuan ini dapat sebagai masukan untuk penelitian selanjutnya untuk mencermati secara lebih detail dan akurat pengaruh Kemandirian.

\section{PENUTUP}

Berdasarkan pembahasan yang telah diuraikan di taas maka dapat ditarik beberapa simpulan sebagai berikut:

1. Hasil belajar TIK siswa SMP Swasta Dwi Tunggal Tanjung Morawa yang diajar dengan strategi pembelajaran Tutor Sebaya lebih baik daripada hasil belajar TIK siswa yang diajar dengan pembelajaran Modul.

2. Hasil belajar TIK siswa yang mempunyai Kemandirian tinggi lebih baik dari pada hasil belajar TIK siswa yang mempunyai Kemandirian rendah.

3. Terdapat interaksi antara strategi pembelajaran dengan Kemandirian dalam memberikan pengaruh terhadap hasil belajar TIK siswa SMP Swasta Dwi Tunggal Tanjung Morawa, siswa yang mempunyai Kemandirian tinggi lebih baik diajar dengan strategi pembelajaran Tutor Sebaya, sedangkan siswa yang mempunyai Kemandirian rendah lebih baik diajar dengan strategi Modul.

\section{DAFTAR PUSTAKA}

Ahmadi, Abu. 2009. Psikologi Umum. Jakarta: Rineka Cipta.
Anderson, LW,. Krathwohl, D.R. 2001. A Taxonomy for Learning, Teaching, and Assessing. New York: Addison Wesley Longman, Inc.

Berliner, David and Robert, C. Calfee. 1996. Hand Book of Educational Psychology. New York: MacMillan Library Refrence.

Davies, Ivor, K. 1981. Instructional Technique. New York: McGraw-Hill Book Company.

Daryanto. 2013. Menyusun Modul: Bahan Ajar Untuk Persiapan Guru Dalam Mengajar. Yogyakarta: Gava Media.

Depdiknas. 2004. Kurikulum 2004 Mata Pelajaran Ketrampilan Komputer dan Pengelolaan Informasi. Jakarta: Depdiknas.

Dick, W. dan Carey, L. 2005. The Systematic Design of Instruction. USA: Scott, Foesman and Company.

Djamarah., Zain, Aswan. 2010. Strategi Belajar Mengajar. Jakarta: Rineka Cipta.

Gagne, RM. 1987. Instructional Technology: Foundations. London: Lauwrence Erlbaums Associates.

Hamalik, Oemar. 2011. Kurikulum Dan Pembelajaran. Jakarta: PT Bumi Aksara.

Hamalik, Oemar. 2010. Perencanaan Pengajaran Berdasarkan Pendekatan Sistem. Jakarta : PT Bumi Aksara.

Hamid. A. 2009. Teori Belajar dan Pembelajaran. Medan : Program Pascasarjana Unimed.

Hegerhahn, B.R., and Olson, M.H. 2008. Theories of Learning (Teori Belajar). Jakarta: Kencana.

Istarani. 2012. Kumpulan 39 Metode Pembelajaran. Medan: CV Iscom Medan.

Jhonson and Medinnus. 1989. The Natural and Condition of Learning: New York: Prentice Hall, Inc.

Kemp, J, E. 1994. The Intructional Design Process: A Plan for Unit and Course Development. California: Fearon Publishers, Inc.

Masrun, dkk. 1986. Studi Mengenal Kemandirian Pada Penduduk di Tiga Suku (Jawa, Batak, Bugis). Yogyakarta: FE-UGM. Laporan Penelitian.

Miarso , Y.H. 2004. Menyemai Benih Teknologi Pendidikan. Jakarta: Kencana. 
Muhibbinsyah. 2003. Psikologi Belajar. Bandung: Raja Grafindo Persada.

Mulyasa, E. 2009. Menjadi Guru Profesional Menciptakan Pembelajaran Kreatif dan Menyenangkan. Bandung: Rosda Karya.

Mulyasa, E. 2006. Kurikulum Berbasis Kompetensi: Konsep, Karakteristik, dan Implementasi. Bandung: Rosda Karya.

Nasution, S. 1987. Berbagai Pendekatan Dalam Proses Belajar dan Mengajar. Jakarta: Bina Aksara.

Regeluth, C.M. 1983. Instruksional Design Theories and Models : An overview of their Currect Status. London : Lauwrence Erlbaums Associates.

Rohani, Ahmad. 2010. Pengelolaan Pengajaran. Jakarta: Rineka Cipta.

Rusman. 2011. Model-Model Pembelajaran: Mengembangkan Profesionalisme Guru. Jakarta: Rajawali Pers.

Sabri, H. Ahmad. 2010. Strategi Belajar Mengajar: Micro Teaching. Bandung: Quantum Teaching.

Sanjaya, Wina. 2011. Strategi Pembelajaran Berorientasi Standar Proses Pendidikan. Jakarta: Kencana.
Sardiman, A.M., 2011. Interaksi \& Motivasi Belajar Mengajar. Jakarta : Rajawali Pers.

Seifert, Kelvin. 2012. Pedoman Pembelajaran \& Intruksi Pendidikan. Jogjakarta: IRCiSoD.

Slameto. 2010. Belajar dan Faktor-Faktor yang Mempengaruhinya. Jakarta: Rineka Cipta.

Slavin, Robert. E. 2011. Psikologi Pendidikan: Teori dan Praktik. Jakarta: PT Indeks.

Sudjana. 2001. Metode \& Tehnik Pembelajaran Partisipatif. Bandung: Falah Production.

Sudjana, Nana., Rivai, Ahmad. 2001. Teknologi Pengajaran. Bandung: Sinar Baru Algensindo.

Sugiyono. 2011. Stastika Untuk Penelitian. Bandung: Alfabeta.

Suparman, Atwi. 2001. Desain Instruksional. Jakarta: PAU-PPAI Universitas Terbuka.

UU RI No 14 Tahun 2005 Tentang Guru dan Dosen.

UU RI No 20 Tahun 2003 Tentang Sistem Pendidikan Nasional.

Wena, Made. 2011. Strategi Pembelajaran Inovatif Kontemporer: Suatu Tinjauan Konseptional Operasional. Jakarta: Bumi Aksara. 